\title{
SZYMON STUŁKOWSKI \\ Kapłan sługą komunii. Od osobistej więzi do posłannictwa jedności
}

Przyjęty przez Konferencję Episkopatu Polski Program duszpasterski dla Kościoła w Polsce na lata 2010-2013 ukierunkowuje działania duszpasterskie na czynienie Kościoła domem i szkołą komunii. Wskazany przez biskupów obszar zadań duszpasterskich nawiązuje do wypowiedzi Jana Pawła II z listu apostolskiego na nowe tysiąclecie chrześcijaństwa Novo millennio ineunte. Papież pisał: Czynić Kościót domem i szkoła komunii: oto wielkie wyzwanie, jakie czeka nas $w$ rozpoczynajacym sie tysiacleciu, jeśli chcemy pozostać wierni Bożemu zamystowi, a jednocześnie odpowiedzieć na najgłębsze oczekiwania świata (NMI 43). Przed Kościołem w Polsce otworzyła się możliwość wypracowania długoletniego programu, którego myślą przewodnią byłaby troska o to, aby każdy człowiek doświadczył głębokiej jedności z Bogiem, jedności uzdalniającej do budowania dojrzałych i odpowiedzialnych relacji z bliźnimi. Komisja Duszpasterstwa Konferencji Episkopatu Polski, pracująca pod kierownictwem abp. Stanisława Gądeckiego oraz we współpracy z pastoralistami z różnych ośrodków teologicznych w Polsce, przygotowała zarys projektu Programu duszpasterskiego dla Kościoła $w$ Polsce na okres 20 lat. Jak relacjonuje arcybiskup Gądecki: (...) księża biskupi zebrani na Konferencji w dniach 6-7 października 2009 roku nie przyjęli tego dtugofalowego projektu, zalecają skrócenie go do okresu 3 lat. W zwiazku z tym zespót pastoralistów wypracowat szczegóty programu na 3 najbliższe lata. Tematem wiodqcym pozostaje wybrany wcześniej: »Kościót domem $i$ szkoła komunii«. Natomiast hasła na kolejne trzy lata brzmiq: »W komunii z Bogiem«, »Kościót naszym domem« oraz »Być sola ziemi«. Ten projekt pro-

Szymon S T U Ł K O W S K I, ks. dr, adiunkt w Zakładzie Teologii Pastoralnej WT UAM w Poznaniu, sekretarz Komisji Duszpasterstwa Konferencji Episkopatu Polski, Poznań, e-mail: szymons@amu.edu.pl 
gramu księża biskupi zatwierdzili na zebraniu plenarnym KEP dnia 26 listopada $2009 \mathrm{roku}^{1}$. Szkoda, że pasterze Kościoła katolickiego w Polsce nie odważyli się pójść za proroczą wizją wskazaną przez Jana Pawła II, by zagadnieniu czynienia Kościoła domem i szkołą komunii poświęcić przynajmniej drugą i trzecią dekadę nowego tysiąclecia. Już sam fakt sformułowania tematu inaczej niż proponował to papież wskazuje na brak gotowości przyznania się do faktu, że Kościół wciąż na nowo musi się uczyć, jak stawać się komunią.

\section{Centralny temat Vaticanum II}

Eklezjologia communio to główny temat myślenia o Kościele, zawarty w nauczaniu Soboru Watykańskiego II. Dwadzieścia lat po zakończeniu Vaticanum II Jan Paweł II zwołał Nadzwyczajny Synod Biskupów, który miał jeszcze raz pochylić się nad dorobkiem ostatniego Soboru. W Relacji końcowej biskupi napisali, że: Pojęcie »koinonia - communio «, oparte na Piśmie Świętym, cieszyło się w Kościele starożytnym i cieszy do dziś w Kościołach Wschodu wielkq czciq. Stad Sobór Watykański II uczynit wiele, aby Kościót byt wyraźniej rozumiany jako »komunia $i$ bardziej konkretnie jako »komunia « urzeczywistniany ${ }^{2}$. Co oznacza stowo »communio «? - pytają biskupi. W Relatio finalis czytamy: Podstawowy sens odnosi się do zjednoczenia z Bogiem przez Jezusa Chrystusa w Duchu Świętym. To zjednoczenie dokonuje się w Stowie Bożym i sakramentach (Lumen gentium, 11). »Komunia « $z$ Ciatem Chrystusa w Eucharystii oznacza $i$ sprawia, czyli buduje wewnętrzne zjednoczenie (»komunię«) wszystkich wiernych w ciele Chrystusa, którym jest Kościót (por. 1 Kor 10,16n). Kongregacja Nauki Wiary opublikowała w 1992 r. list Communionis notio, w którym podkreślono, że pojęcie kościelnej komunii musi być rozumiane $w$ kontekście całego nauczania biblijnego i tradycji patrystycznej, gdzie »komunia« zaktada zawsze podwójne odniesienie: »wertykalne" (komunia z Bogiem) $i$ »horyzontalne "(komunia między ludźmi) ${ }^{4}$. W adhortacji apostolskiej Christifideles laici Jan Paweł II pokazał, jakie elementy składają się na rozumienie Kościoła jako komunii (por. ChL 18-31). W liście Novo millennio ineunte zaznaczył natomiast, że - wymagająca zdecydowanego podjęcia i planowania

${ }^{1}$ S. G ą d e c k i: Stowo wstępne. W: Komisja Duszpasterstwa Konferencji Episkopatu Polski: Rok 2010/2011. W komunii z Bogiem. Kościót domem i szkoła komunii. Program duszpasterski dla Kościoła w Polsce na lata 2010-2013. Poznań 2010 s. 9.

${ }^{2}$ Relacja końcowa z Nadzwyczajnego Synodu Biskupów. „Przegląd Katolicki”. R. 74: 1986 nr 4 pkt II, C, 1.

${ }^{3}$ Tamże.

${ }^{4}$ Kongregacja Nauki Wiary: List do Biskupów Kościoła katolickiego o niektórych aspektach Kościoła pojętego jako komunia »Communionis notio« (28 maja 1992). W: W trosce o petnie wiary. Dokumenty Kongregacji Nauki Wiary 1966-1994. Tarnów 1995 nr 3 s. 391. 
na płaszczyźnie Kościoła powszechnego i Kościołów partykularnych - sprawa aktualizacji kościelnej komunii jest ucieleśnieniem i objawieniem samej istoty tajemnicy Kościoła (NMI 42).

\section{Komunia darem i zadaniem}

Sformułowanie tematu: Kapłan sługa komunii. Od osobistej więzi do postannictwa jedności wymaga pewnego uszczegółowienia. Po pierwsze, kapłan na mocy sakramentu święceń jest osobą szczególnie predestynowaną do tego, by trwać w jedności z Bogiem oraz z braćmi na wzór Boga w Trójcy Świętej jedynego. Po drugie, kapłan został powołany, by pomagać ludziom budować ich osobistą więź z Panem Bogiem, a także wyrastającą z tego doświadczenia jedność pomiędzy ludźmi. Chodzi o komunię w podwójnym tego słowa znaczeniu. Najpierw o osobistą relację kapłana z Bogiem i z bliźnimi, potem o posługę na rzecz komunii między człowiekiem a Bogiem oraz między braćmi. Komunia z Bogiem jest dla człowieka niezasłużonym darem samego Stwórcy. To On w swoim Synu, Jezusie Chrystusie, wychodzi do nas, by odbudować to, co zburzył grzech pierworodny. Przez sakramentalne zanurzenie w sakramencie chrztu świętego dokonuje się zjednoczenie z Chrystusem i włączenie w Jego potrójną misję: kapłańską, prorocką i królewską. Od tego momentu zjednoczenie z Bogiem, które jest darem, staje się także zadaniem; chrześcijanin zostaje powołany, by stawać się ofiarą miłą Bogu, by dzielić się wiarą oraz służyć Bogu i bliźnim. Owa komunia $\mathrm{z}$ braćmi to owoc zakorzenienia w tajemnicy Boga. Im bardziej człowiek staje się „mistyczny”, tym bardziej jest braterski i solidarny. Wspólnota z braćmi stanowi także konsekwencję przyjęcia eklezjologii komunii i życia nią na co dzień, czyli jest również skutkiem duchowego i intelektualnego rozwoju osoby.

\section{Więź kapłana z Bogiem}

Jak zapisał ewangelista Marek: Jezus przywołał do siebie tych, których sam chciat, ustanowit dwunastu, aby Mu towarzyszyli (Mk 3,14). Ten fragment, jak pisze Andrzej Czaja, (...) daje najistotniejszq odpowiedź na pytanie: po co postuga kaptańska w Kościele Chrystusowym? Postuga ta jest po to, aby byli tacy, którzy by Chrystusowi zawsze towarzyszyli. Być kapłanem, to być towarzyszem Chrystusa, Jego giermkiem, który jeśli trzeba, to ma za Niego oddać życie ${ }^{5}$. Troska o rozwój własnej duchowości, o osobistą relację z Chrystusem, który zanurzył człowieka w swojej zbawczej śmierci, wybrał, powołał i ustanowił swoim

${ }^{5}$ A. C z a j a: Kaptaństwo w Kościele katolickim. „Zeszyty Odnowy w Duchu Świętym”. R. $2010 \mathrm{nr} 4(109)$ s. 7. 
kapłanem, to przede wszystkim życie sakramentalne, sakrament pojednania i pokuty, Eucharystia celebrowana i przeżywana jako ofiara Chrystusa i uczta z Mistrzem, to modlitwa osobista, medytacja, formacja permanentna: rekolekcje, dni skupienia oraz studium. Jak przypomniał w swoim nauczaniu Jan Paweł II, w relacji człowieka z Bogiem istnieje pierwszeństwo łaski (por. NMI 38). To Bóg zawsze wychodzi pierwszy, to On inicjuje naszą wzajemną więź. Dlatego życie każdego chrześcijanina, a szczególności kapłana, winno mieć „responsoryjny charakter”. Nie można zbudować żywej, osobowej więzi z Bogiem, jeśli On nie wezwie człowieka do budowania tej relacji. Od każdego człowieka z osobna zależy, czy podtrzymywanie i pielęgnowanie tej więzi to tylko obowiązek, czy też wynika ono z potrzeby serca. Jan Paweł II przestrzegał kapłanów: Istnieje pewna pokusa, która od zawsze zagraża życiu duchowemu każdego człowieka, a także działalności duszpasterskiej: jest niq przekonanie, że rezultaty zależq od naszej zdolności działania i planowania. To prawda, że Pan Bóg oczekuje od nas konkretnej wspótpracy z Jego łaska, a zatem wzywa nas, byśmy w stużbie Jego Królestwu wykorzystywali wszystkie zasoby naszej inteligencji $i$ zdolności dziatania. Biada jednak, gdybyśmy zapomnieli, że bez Chrystusa »nic nie możemy uczynić" [por. J 15,5] (NMI 38). Komunia kapłana z Bogiem staje się znakiem dla świata. Pełniąc swoje podstawowe funkcje: nauczania, uświęcania i pasterzowania, kapłan winien mieć świadomość, że u podstaw jego udziału w kapłaństwie hierarchicznym leży Chrystusowe obdarowanie ${ }^{6}$. Jak pisze Henryk Witczyk, (...) podstawowym zadaniem, jakie maja do spetnienia kapłani, jest być sakramentem Jezusa Chrystusa - Kapłana, Pośrednika między ludźmi (grzesznikami) i Bogiem (świętym). Maja być widzialnym znakiem niewidzialnej obecności Jezusa, o którym autor Listu do Hebrajczyków mówi: »Przeto i zbawić na wieki może catkowicie tych, którzy przez Niego zbliżaja się do Boga, bo zawsze żyje, aby się wstawiać za nami « $(\mathrm{Hbr} 7,25)^{7}$.

\section{Więź z braćmi}

Fundamentem relacji kapłana z bliźnimi winna być najpierw duchowość chrzcielna. Przez sakrament chrztu świętego - jak naucza Kościół - wszyscy jesteśmy równi pod względem godności i działania. Równość w godności dotyczy bycia dzieckiem Bożym; przez sakramentalne zanurzenie w śmierci Chrystusa, rodzimy się do nowego życia. Równość w działaniu dotyczy powołania do szerzenia Królestwa Bożego (w zależności od stanu i powołania). Warto zastanowić się, czy nauczanie Kościoła opisuje rzeczywistość, w której żyjemy i którą

\footnotetext{
${ }^{6}$ Tamże, s. 10.

${ }^{7}$ H. W i t c z y k: Kaptan w świecie wspótczesnym (Hbr 5,1-10). „Zeszyty Odnowy w Duchu Świętym”. R. 2010 nr 4(109) s. 13-14.
} 
współtworzymy, czy jest bardziej postulatem, który mamy zrealizować? Jak wygląda nasza duchowość chrzcielna? Wystarczy zapytać, czy ludzie znają datę swojego chrztu, przyjrzeć się praktyce celebrowania w parafiach tego sakramentu oraz Wigilii Paschalnej, postawić pytanie o symbolikę paschału i praktykę korzystania ze świecy w liturgii roku kościelnego.

Po doświadczeniu chrzcielnym fundamentem relacji między kapłanami winna być świadomość, że zostali oni wybrani i powołani przez Najwyższego Kapłana, Jezusa Chrystusa do pełnienia tej samej misji w Kościele i świecie. To On, znając różnorodność i inność poszczególnych osób, zapragnął, aby stali się Jego kapłanami. Takie spojrzenie otwiera możliwość współpracy z każdym współbratem, nawet jeśli - patrząc po ludzku - dzieli ich bardzo wiele (rok urodzenia, osobowość, talenty, wykształcenie...). W dekrecie Presbyterorum ordinis (8) Soboru Watykańskiego II czytamy: Wszyscy prezbiterzy, ustanowieni przez święcenia $w$ stanie kaptańskim, zwiqzani sq z sobq najściślejszym braterstwem sakramentalnym; szczególnie zaś w diecezji, której stużbie sq oddani pod zwierzchnictwem własnego biskupa, tworza jeden zespót prezbiterów. Natomiast w Katechizmie Kościoła katolickiego podkreśla się, że: Jedność prezbiterium wyraża się w liturgii poprzez zwyczaj, zgodnie z którym podczas obrzędu święceń po biskupie na nowo wyświęconego wkładaja ręce także kapłani (KKK $1568)$.

Benedykt XVI w Liście na rozpoczęcie Roku Kapłańskiego pisał: Z komunii między kaptanami (...) może rzeczywiście wyptywać »cenny impuls do odnowionego zaangażowania Kościoła w głoszenie Ewangelii nadziei i mitości i dawanie jej świadectwa we wszystkich zakatkach świata«. Chciałbym też dodać, odwołujac się do adhortacji apostolskiej »Pastores dabo vobis « papieża Jana Pawta II, że postuga kaptańska ma radykalna »forme wspólnotowq $i$ może być wypetniona tylko w komunii kaptanów ze swym biskupem. Trzeba, aby ta komunia między kaptanami, a także ze swym biskupem, majaca swe podstawy w sakramencie święceń i przejawiająca się $w$ koncelebracji eucharystycznej, wyrażata się $w$ różnych konkretnych formach rzeczywistego i afektywnego braterstwa kaptańskiego. Tylko $w$ ten sposób kaptani będq umieli żyć $w$ petni darem celibatu $i$ będa zdolni do sprawiania, by rozkwitały wspólnoty chrześcijańskie, w których powtarzane sq cuda pierwszego przepowiadania Ewangelii.

Jedność kapłanów między sobą nie zamyka ich na komunię z wiernymi świeckimi. Ciekawą myśl prezentuje Gisbert Greshake, wskazując na Chrystusa, który nie „naruszał” ani nie „rozsadzał” communio swoich uczniów, ale ją - jako Głowa - podtrzymywał $\mathrm{w}$ istnieniu ${ }^{8}$. Również ta szczególna, urzędowo-

\footnotetext{
${ }^{8}$ Por. G. Gr e s h a k e: Być kaptanem dzisiaj. Poznań 2010 s. 155-156.
} 
kapłańska misja nie odtacza nikogo od wspólnoty ochrzczonych, lecz głębiej wprowadza w życie Kościoła. Utworzony przez Chrystusa urzqd oraz napetniona Duchem Świętym i wyposażona w Jego dary wspólnota pozostałych ochrzczonych przeżywaja we wzajemnych do siebie relacjach swa zależność od jedynego Pana i Najwyższego Kapłana ${ }^{9}$. G. Greshake wskazuje, że szczególny akcent w posłudze urzędu położono na działanie dośrodkowe. Kaptan, $w$ imię Chrystusa $i$ mocq Jego władzy, ma przez nauczanie, uświęcanie i kierowanie gromadzić wspólnote $i$ utrzymywać $w$ jedności ${ }^{10}$. Zadaniem pozostałych chrześcijan jest działanie odśrodkowe, czyli misja. Jako ochrzczony i bierzmowany oraz umacniany przez Eucharystię $i$ istniejąca już komunię, każdy chrześcijanin jest powotany do przenikania duchem Ewangelii $i$ wtaczania w wielki Boży dynamizm jedności owej czastki świata, powierzonej mu w rodzinie i zawodzie »w politycznej odpowiedzialności $i w$ chwilach odpoczynku « ${ }^{11}$. Patrząc w ten sposób, widzimy, że misja świeckich nie jest mniej cenna niż misja kapłana. Jak zauważa H. J. Görtz, misja wiernych świeckich jest najbardziej pierwotnq realizacja Kościoła $^{12}$, ponieważ misją Kościoła jest działalność skierowana na świat ${ }^{13}$.

\section{W służbie jedności z Bogiem}

Kapłan jest wezwany i powołany przez Boga, by być szczególnym pomocnikiem w procesie budowania przez człowieka komunii Bogiem. Już samo łacińskie określenie kapłana - pontifex (budowniczy mostów) - wskazuje na jego szczególną misję w relacjach między Bogiem a ludźmi, do których zostaje posłany. Most łączy dwa brzegi. Przypomnijmy jeszcze raz prawdę o pierwszeństwie łaski (por. NMI 38), by zaznaczyć, że inicjatywa komunii zawsze pochodzi od Boga, jest Jego darem. Kapłan powinien dawać przykład swoim życiem, świadczyć o osobistej relacji z Bogiem. Ciagle aktualne pozostają słowa Pawła VI, do których odwołuje się on w adhortacji apostolskiej Evangelii nuntiandi (EN 41): człowiek naszych czasów chętniej stucha świadków aniżeli nauczycieli; a jeśli stucha nauczycieli, to dlatego, że sq świadkami ${ }^{14}$. Przykład kapłana, emanującego osobistym doświadczeniem Boga i świętością, pozostaje zawsze znakiem dla ludzi wrażliwych na Pana, który przychodzi w drugim człowieku. $W$ Kościele za pierwszy środek ewangelizowania należy uważać świadectwo życia prawdziwie chrześcijańskiego, które trwa w nierozłacznej wspólnocie z Bogiem,

${ }^{9}$ Tamże, s. 156.

${ }^{10}$ Tamże.

${ }^{11}$ Tamże.

${ }^{12}$ H.J. G ö r t z: Das kirchliche Handeln des Laien. ThPh. R. 1991 nr 66 s. 177-191.

${ }^{13}$ Por. G. G r e s h a k e: Być kaptanem dzisiaj, dz. cyt., s. 157.

${ }^{14} \mathrm{P}$ a w e 1 V I: Przemówienie do członków »Consilium de Laicis« (2.10.1974). AAS. R. 1974 nr 66 s. 568 oraz EN 41. 
a zarazem w nieograniczonej goracości ducha poświęcania się dla innych (EN 41). Dosyć często dajemy się dzisiaj uwieść w życiu kaptańskim temu, że trzeba dziatać aktywnie na rzecz zbawienia człowieka $i w$ sytuacji, gdy jest mnóstwo tych różnych dziatań, akcji, przedsięwzięć, obcina się czas dla Boga. A tymczasem pierwsza $i$ podstawowa postuga wobec wiernych jest nasza modlitwa ${ }^{15}$. Chrystus ustanowił - wyposażonych we władzę świętą - szafarzy z myślą o dobru całego Kościoła, aby byli pasterzami ludu Bożego i pomnażali go, dbając, by każdy osiagnął zbawienie (por. LG 8). W Katechizmie Kościoła katolickiego czytamy, że nikt nie może sam sobie głosić Ewangelii albo udzielić łaski (por. KKK 875). Szczególnym narzędziem łaski w kapłańskiej służbie jednania ludzi z Bogiem są sakramenty, zwłaszcza chrztu, pojednania i pokuty oraz Eucharystii. Kapłan, ustanowiony przez Boga mocą święceń, jest szafarzem tych sakramentów, odgrywa niezastąpioną rolę w budowaniu komunii Boga z ludźmi. Bez własnej zasługi - przez wybranie, powołanie i sakramentalne uświęcenie - staje się współpracownikiem Boga w dziele włączania ludzi do wspólnoty Kościoła, uwalniania ich od ciężaru grzechów i budowania wspólnoty mocą ofiary i uczty Jezusa Chrystusa, uobecniających się podczas mszy świętej. Każdy kapłan ma naśladować Chrystusa, Dobrego Pasterza, który szuka zagubionych owiec, by je znaleźć i przyprowadzić do stada. Pasterska miłość kapłana powinna być tak wielka, by potrafił, jak Jezus, oddać życie za braci.

\section{Posługa na rzecz jedności z braćmi}

Kapłańska posługa na rzecz jedności z Bogiem w oczywisty sposób przechodzi w służbę jedności między ludźmi. Prawdziwa więź człowieka z Bogiem owocuje tworzeniem się autentycznych relacji, opartych na fundamencie Bożej miłości. Kapłan jest powołany do tego, by łączyć, jednać ludzi ze sobą, a nie dzielić ich ze względu na różnice, które przecież w naturalny sposób rodzą się i istnieją. Dotyczy to szczególnie sfery polityki i podziałów ze względu na przekonania. Kapłan winien stawać ponad podziałami, powinien być człowiekiem otwartym na wszystkich, do których został posłany. Misją prezbitera jest życie duchowością komunii i krzewienie jej wśród braci. Duchowość komunii to duchowość zrozumienia zamysłów Bożych, solidarności międzyludzkiej, szukania tego, co łączy, a nie tego, co dzieli, to duchowość przebaczenia, wzajemnego upominania się, gdy błądzimy, dawania świadectwa. Duchowość komunii to duchowość miłości i odpowiedzialności, troski o wzajemny rozwój. A wzrastać możemy tylko razem, pobudzając w sobie wiarę, miłość i nadzieję (por. NMI 43). W izolacji człowiek marnieje. Wspólnota jest glebą, na której wyrasta ziarno ludzkiego życia. Tu zapuszcza korzenie. I tu owocuje. Program Chrystusa to

\footnotetext{
${ }^{15}$ A. C z a j a: Kaptaństwo w Kościele katolickim, dz. cyt., s. 12.
} 
program jedności w Nim: Ja w nich - a Ty we Mnie; Oby się tak zespolili w jedno, aby świat poznat, żeś Ty mnie postat $i$ żeś Ty ich umiłowat, tak jak mnie umitowałeś (J 17,23). Tak zjednoczeni chrześcijanie stają się światłem świata i solą tej ziemi. Tu dotykamy bardzo ważnej kwestii: jedność uczniów Jezusa nie jest celem samym w sobie. Nasza jedność ma służyć ewangelizacji, aby świat poznał Jezusa, swojego Zbawiciela. Zrozumienie tej dynamiki obliguje nas do podejmowania wysiłku, by być jedno. Nie dla własnej przyjemności, wygody, nie dla tzw. „oka” ludzi, ale dla ewangelizacji. Takie spojrzenie pomaga zrozumieć, że budowanie jedności między ludźmi, jeśli ma być drogą naśladowania Chrystusa, nie może być pozbawione wymiaru Krzyża.

\section{Implikacje pastoralne}

Kościół posoborowy na nowo odkrył i podkreślił wartość życia we wspólnocie, w komunii z Bogiem i braćmi. To jest odkrycie, które może wiele zmienić: nasz styl życia, duszpasterstwo (szczególnie, gdy myślimy o komunii w szerszym kontekście aniżeli tylko w wymiarze wspólnoty kapłanów), obraz parafii, w której posługujemy. Święty Paweł w czwartym rozdziale Listu do Efezjan pisze, że: „Bóg działa we wszystkich i przez wszystkich”.

Kapłańska służba komunii winna być owocem życia eklezjologią komunii zarówno w wymiarze wewnętrznym - duchowym, jak i zewnętrznym - duszpasterskim. Jeśli nie zaistnieje duchowy fundament komunii z Bogiem przez Chrystusa w Duchu Świętym, to wszelkie formy zewnętrznej jedności nie ostoją się w godzinie próby, będą tylko atrapą jedności!

Aby eklezjologia i duchowość komunii mogły prawdziwie zaistnieć i prawidłowo się rozwijać, wymaga to wsparcia w formie uczenia się współpracy między kapłanami, między kapłanami a wiernymi świeckimi oraz pracy w zespole. Dotyczy to zarówno formacji w seminariach duchownych i na wydziałach teologicznych, jak i stałej formacji prezbiterów.

Duchowość komunii wymaga także solidnego wsparcia w formie motywowania kapłanów do pracy w zespole. Warto dostrzec, nagłaśniać i doceniać sytuacje, w których kapłani potrafią owocnie i skutecznie współpracować zarówno ze sobą, jak i ze świeckimi. Taką współpracę należy podejmować w ramach parafii, dekanatu, miasta, diecezji, regionu i całej Ojczyzny. 